\title{
COVID-19 infection mortality risk in Iranian patients with type 2 diabetes, hypertension and obesity
}

Mahdi Shadnoush, ${ }^{1}$ Soghra Rabizadeh, ${ }^{2}$ Alireza Esteghamati, ${ }^{2}$ Manouchehr Nakhjavani, ${ }^{2}$ Nasrin Baiat Paridari, ${ }^{3}$ Mostafa Khoshabi, ${ }^{4}$ Armin Rajab ${ }^{2}$ and Fatemeh Ghaemi ${ }^{5}$

${ }^{1}$ Department of Clinical Nutrition, Faculty of Nutrition and Food Technology, Shahid Beheshti University of Medical Sciences, Tehran, Islamic Republic of Iran ${ }^{2}$ Endocrinology and Metabolism Research Center, Vali-Asr Hospital, Tehran University of Medical Sciences, Tehran, Islamic Republic of Iran.

${ }^{3}$ Non-Communicable Disease Treatment Group, Ministry of Health and Medical Education, Tehran, Islamic Republic of Iran. ${ }^{4}$ Department of Geospatial Information Systems, Center of Excellence in GIS, K.N. Toosi University of Technology, Tehran, Islamic Republic of Iran. ${ }^{5}$ Department of Transplantation and Disease Management, Ministry of Health and Medical Education, Tehran, Islamic Republic of Iran (Correspondence to: F. Ghaemi: Ghaemifa77@ gmail.com).

\begin{abstract}
Background: Diabetes mellitus and hypertension are highly prevalent among patients with severe COVID-19.

Aims: To study the mortality risk of COVID-19 infection in patients with type 2 diabetes and additive effect of hypertension and obesity in the Iranian population.
\end{abstract}

Methods: This was a cross-sectional survey of the national COVID-19 registry from the Iranian Ministry of Health. The medical status of 22002 patients with COVID-19 between 1 March and 30 April 2020 was analysed.

Results: Patients with type 2 diabetes had a higher risk of mortality with an odds ratio (OR) of 1.67 [95\% confidence interval (CI): 1.53-1.82, P < 0.001]. The risk of mortality was also high in patients with diabetes and hypertension, with an odds ratio of 1.76 (95\% CI: 1.56-1.99, $\mathrm{P}<0.001)$. The odds ratio of the risk of mortality in patients with diabetes, hypertension and obesity was 1.87 (95\% CI: $1.35-2.58, \mathrm{P}<0.001)$.

Conclusion: Type 2 diabetes, hypertension and obesity each predict mortality in Iranian patients with COVID-19, and when they are present together, patients have a greater risk of mortality.

Keywords: COVID-19, diabetes mellitus, hypertension, obesity, mortality, Iran

Citation: Shadnoush M; Rabizadeh S; Esteghamati A; Nakhjavani M; Paridari NB; Khoshabi M; et al. COVID-19 infection mortality risk in Iranian patients with type 2 diabetes, hypertension and obesity. East Mediterr Health J. 2022;28(3):221-224 https://doi.org/10.26719/emhj.21.056

Received: 10/11/20; accepted: 15/06/21

Copyright @ C World Health Organization (WHO) 2022. Open Access. Some rights reserved. This work is available under the CC BY-NC-SA 3.o IGO license (https://creativecommons.org/licenses/by-nc-sa/3.0/igo)

\section{Introduction}

COVID-19 is a rapidly spreading global pandemic. At the time of writing, there had been $>157$ million cases and $>3274000$ deaths from COVID-19 reported worldwide (1). The Islamic Republic of Iran is known as the hotspot of COVID-19 in the Middle East (2), with around 2640000 cases and $>74000$ deaths recorded (1). Diabetes mellitus (DM) is associated with higher mortality risk in hospitalized patients with COVID-19 (3), which was observed in previous coronavirus epidemics, including the Middle East respiratory syndrome (4), and severe acute respiratory syndrome (5). Patients with diabetes have an increased risk of infection. Also, severe COVID-19 might worsen diabetes through direct effects on $\beta$-cell function, and could be a precipitating factor for acceleration of acute complications of diabetes (6). Patients with type 2 diabetes mellitus usually suffer from other comorbidities such as obesity and hypertension, which can accentuate the poor prognosis and mortality risk of COVID-19 (7, 8). Furthermore, among patients with severe COVID-19, type $2 \mathrm{DM}$ (T2DM) and hypertension are more prevalent (9).

Although the number of publications about COVID-19 has progressively increased in the Middle East and North Africa (MENA), there is a need for accurate data on the epidemiology of COVID-19 from all MENA countries (10). In this study, we studied the mortality risk in COVID-19 patients in the Islamic Republic of Iran with comorbid T2DM and the additive effects of hypertension and obesity.

\section{Methods}

This was a cross-sectional survey from 1 March to 30 April 2020 of the national COVID-19 registry from the Iranian Ministry of Health, including 22002 patients with COVID-19 from 58 medical universities located across 31 provinces. The following clinical information was recorded daily from all medical centres: demographics, symptoms, signs, and physical examination on admission, medical and medication history, anthropometrics, laboratory test results (including complete blood count and inflammatory markers), imaging findings, therapeutic interventions, and disease outcomes. Suspicion of diagnosis of COVID-19 was based on clinical signs and symptoms as well as computed tomography, and definite diagnosis was based on a positive reverse transcription polymerase chain reaction (RT-PCR) nasopharyngeal swab test (11).

T2DM was defined according to positive medical history, consumption of antidiabetic medication, or glycated haemoglobin $\geq 6.5 \%$ and fasting blood 
glucose $\geq 126 \mathrm{mg} / \mathrm{dL}$. Hypertension was defined based on medical history of patients or use of antihypertensive medication. Obesity was defined as body mass index $\left(\right.$ BMI) $\geq 30 \mathrm{~kg} / \mathrm{m}^{2}$.

Data were analysed using SPSS for Windows version 24 (Chicago, IL, USA). Logistic regression analysis was performed to show the adjusted effect of T2DM, hypertension and obesity on the mortality risk of COVID-19. Hence, sex, age, BMI, smoking, and comorbidities were included in the model.

The study was performed in accordance with the ethical standards of the institutional and/or national research committee and with the 1964 Helsinki Declaration and its later amendments or comparable ethical standards. Informed consent was obtained from all individual participants included in the study.

\section{Results}

There were 22002 patients with suspicious diagnoses of COVID-19, and 17476 (79.4\%) had definite diagnoses with positive RT-PCR nasopharyngeal swab test results. The mean age was 51.8 (21.1) years and $41.7 \%$ were female (Table 1). Among patients with positive RT-PCR tests, 7713 (44.1\%) had T2DM: 3016 (39.1\%) female and 4697 (60.9\%) male (Table 2), and 6060 (34.7\%) had a history of hypertension (Table 1). Among patients with T2DM, 4167 (54\%) had a history of hypertension and 5370 (69.6\%) were overweight or obese (Table 2).

Logistic regression analysis showed that patients with $\mathrm{T} 2 \mathrm{DM}$, hypertension or obesity had a significantly higher risk of mortality (Table 3). The risk of mortality was significantly higher in patients with T2DM and hypertension, or $\mathrm{T} 2 \mathrm{DM}$, hypertension and obesity than in patients with any of the conditions alone.

\section{Discussion}

The current study shows that Iranian patients with COVID-19 with diabetes or hypertension or both comorbid conditions had a significantly increased risk of mortality. When obesity was added the mortality risk increased. Our results agree with a previous study in the MENA region by Alguwaihes et al. which showed that patients with DM had a significantly higher mortality rate than patients without DM (20.5\% vs $12.3 \%)$ (12).

Due to the high prevalence of diabetes worldwide, these patients represent a large percentage of the

\begin{tabular}{|c|c|}
\hline \multicolumn{2}{|l|}{ Characteristics } \\
\hline \multicolumn{2}{|l|}{ Sex } \\
\hline Female & $7281(41.7 \%)$ \\
\hline Male & $10195(58.3 \%)$ \\
\hline Age, mean (SD) & 51.8 (21.1) years \\
\hline hypertension & $6060(34.7 \%)$ \\
\hline T2DM & $7713(44.1 \%)$ \\
\hline Obesity $\left(\mathrm{BMI}>30 \mathrm{~kg} / \mathrm{m}^{2}\right)$ & $1226(5.6 \%)$ \\
\hline Overweight $\left(25<\mathrm{BMI}<30 \mathrm{~kg} / \mathrm{m}^{2}\right)$ & $6816(39.0 \%)$ \\
\hline Smoking & $1933(8.78 \%)$ \\
\hline
\end{tabular}

Table 2 Characteristics of 7713 patients with type 2 diabetes and COVID-19

\begin{tabular}{|c|c|}
\hline \multicolumn{2}{|c|}{ Characteristics } \\
\hline Sex & \\
\hline Female & $3016(39.1 \%)$ \\
\hline Male & $4697(60.9 \%)$ \\
\hline Age, mean (SD) & $62.81(12.98)$ years \\
\hline Hypertension & $4167(54.0 \%)$ \\
\hline Obesity $\left(\mathrm{BMI}>30 \mathrm{~kg} / \mathrm{m}^{2}\right)$ & $442(5.7 \%)$ \\
\hline Overweight $\left(25<\mathrm{BMI}<30 \mathrm{~kg} / \mathrm{m}^{2}\right)$ & $4928(63.9 \%)$ \\
\hline Smoking & $718(9.3 \%)$ \\
\hline
\end{tabular}

Results presented as number (percentage), unless otherwise stated. BMI = body mass index; $S D=$ standard deviation

COVID-19 population. Mantovani et al. in a meta-analysis of 83 studies involving 78874 patients hospitalized with COVID-19 in 2020 showed that the pooled prevalence of diabetes was $14.34 \%$. Hospitalized patients with diabetes had a 2-fold higher risk of having severe COVID-19 and a 3-fold increased risk of mortality (13). In our study, $35 \%$ of all patients with COVID-19 had T2DM. DM and hypertension are 2 of the more prevalent comorbidities among patients with COVID-19 (14). Unfortunately, patients with DM, specifically T2DM, suffer from other comorbidities and the additive effect of those diseases results in severe COVID-19. Khan et al. showed that patients with 2 or more comorbidities such as T2DM and hypertension have a 2.5 times greater risk of worse outcome than patients with 1 or no comorbidities (15).

Prevalence of hypertension was high in the general population. Current knowledge about hypertension and COVID-19 is from observational studies that have shown an association between hypertension and critical illness

\begin{tabular}{|c|c|c|c|c|c|}
\hline & B & SE & $\mathbf{P}$ & OR & $95 \% \mathrm{CI}$ \\
\hline $\mathrm{T} 2 \mathrm{DM}$ & 0.513 & 0.044 & $<0.001$ & 1.67 & $1.53-1.82$ \\
\hline HTN & 0.345 & 0.044 & $<0.001$ & 1.41 & $1.29-1.54$ \\
\hline Obesity & 0.254 & 0.080 & 0.001 & 1.29 & $1.10-1.51$ \\
\hline T2DM+HTN & 0.565 & 0.063 & $<0.001$ & 1.76 & $1.56-1.99$ \\
\hline T2DM+HTN+obesity & 0.627 & 0.165 & $<0.001$ & 1.87 & $1.35-2.58$ \\
\hline
\end{tabular}

$\mathrm{CI}=$ confidence interval; $\mathrm{HTN}=$ hypertension; $\mathrm{OR}=$ odds ratio; $\mathrm{SE}=$ standard error $; \mathrm{T} 2 \mathrm{DM}=$ type 2 diabetes mellitus. 
in COVID-19 but causality has not been established $(16,17)$. There is evidence that obesity can increase the severity of COVID-19, and when it coexists with other comorbidities such as diabetes, prognosis is even poorer (18). Moreover, there is a current global pandemic of obesity, which could make COVID-19 more severe (19).

Our study had some limitations. There was a lack of investigation of clinical laboratory factors such as glycaemic control, which can have a significant impact on mortality risk of COVID-19. In some cases, diagnosis of T2DM and hypertension was based on self-report, and some patients were newly diagnosed based on measurement of blood glucose and HbAlc. Unfortunately, the exact type of diagnosis was not available, and there was no information in the national registry about patients who were newly diagnosed with diabetes.

In conclusion, the current study shows that diabetes, hypertension and obesity each predicts mortality in patients with COVID-19 in the Iranian population, and when they coexist, patients have a greater mortality risk. Further studies are needed to investigate the effects of comorbidities on other adverse effects of COVID-19.

\section{Acknowledgement}

We would like to express our appreciation for the cooperation of all persons who contributed to this study.

Funding: This research did not receive any specific grant from funding agencies in the public, commercial, or not-forprofit sectors.

Competing interests: None declared.

\section{Risque de mortalité lié à l'infection par la COVID-19 chez les patients iraniens souffrant de diabète de type 2 , d'hypertension et d'obésité}

\section{Résumé}

Contexte: Le diabète sucré et l'hypertension sont très prévalents chez les patients atteints d'une forme grave de COVID-19.

Objectifs : Étudier le risque de mortalité lié à l'infection par la COVID-19 chez les patients atteints de diabète de type 2 et l'effet additif de l'hypertension et de l'obésité dans la population iranienne.

Méthodes: Il s'agissait d'une enquête transversale du registre national de la COVID-19 du ministère iranien de la Santé et de l'Éducation médicale. L'état de santé de 22002 patients atteints de COVID-19 entre le $1^{\text {er }}$ mars et le 30 avril 2020 a été analysé.

Résultats: Les patients atteints de diabète de type 2 présentaient un risque de mortalité plus élevé avec un odds ratio $(\mathrm{OR})$ de 1,67 [intervalle de confiance (IC) à $95 \%: 1,53-1,82, p<0,001$ ]. Le risque de mortalité était également plus élevé chez les patients diabétiques et hypertendus, avec un OR de 1,76 (IC à $95 \%$ : 1,56-1,99, p < 0,001). L'odds ratio du risque de mortalité chez les patients diabétiques, hypertendus et obèses était de 1,87 (IC à $95 \%: 1,35-2,58, p<0,001$ ).

Conclusion : Le diabète de type 2, l'hypertension et l'obésité permettent respectivement de prédire la mortalité chez les patients iraniens atteints de COVID-19, et lorsqu'ils sont présents ensemble, les patients ont un risque de mortalité plus élevé.

$$
\begin{aligned}
& \text { خطر الوفاة الناجمة عن الإصابة بكوفيد-19 لدى المرضى الإيرانيين المصابين بالنمط } 2 \text { من السكري وارتفاع ضغط } \\
& \text { الدم والسمنة } \\
& \text { مهدي شدنوش، صغرا ربيع زاده، علي رضا إستغاماتي، منوشهر ناخجواني، نسرين بيات باريداري، مصطفى خشابي، أرمين رجب، فاطمة غامي } \\
& \text { الخلاصة } \\
& \text { الخلفية: ينتشر داء السكري وارتفاع ضغط الدم انتشارًا كبيرًا بين المرضى المصابين بحالة وخيمة من كوفيد-19. } \\
& \text { الأهداف: هدفت هذه الدراسة إلى دراسة خطر الوفاة الناجمة عن الإصابة بكوفيد-19 لدى المرضى المصابين بالنمط } 2 \text { من السكري، والتأثير } \\
& \text { الإضافي لارتفاع ضغط الدم و السمنة لدى هده السكان الإيرانيين. }
\end{aligned}
$$

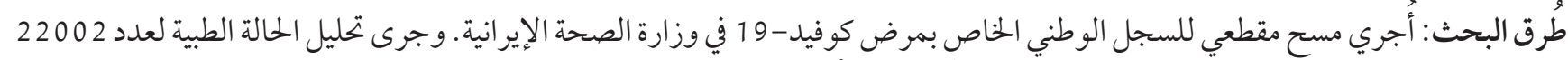

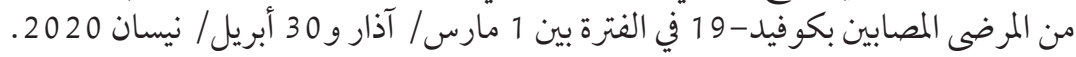

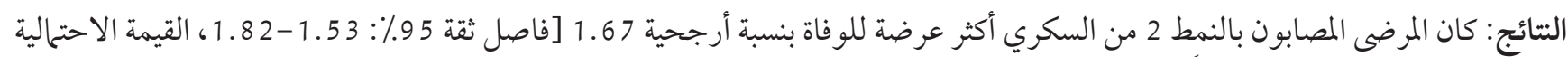

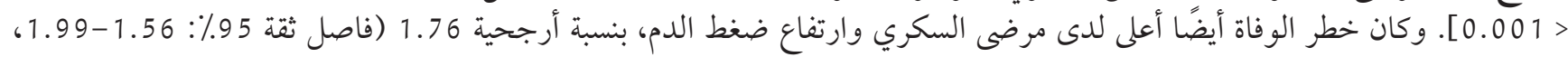




$$
\begin{aligned}
& \text { القيمة الاحتمالية > } 1 \text { القيمة } 0.00 \text { ). وبلغت نسبة أرجحية خطر الوفاة لدى مرضى السكري وارتفاع ضغط الدم والسمنة } 1.87 \text { (فاصل ثقة 95\% }
\end{aligned}
$$

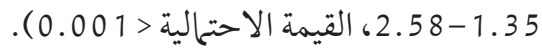

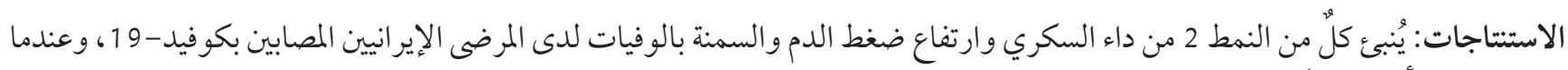

$$
\begin{aligned}
& \text { تترافق تلك الأمر اض معًا، يزداد خطن النط وف مناة المرضى. }
\end{aligned}
$$

\section{References}

1. COVID-19 map. Johns Hopkins Coronavirus Resource Center [website] (https://coronavirus.jhu.edu/map.html, accessed 26 August 2021).

2. In Middle East COVID-19 hotspot Iran, WHO walks the talk [website]. Geneva: World Health Organization; 2021 (https://www. who.int/news-room/feature-stories/detail/in-middle-east-covid-19-hotspot-iran-who-walks-the-talk, accessed 26 August 2021).

3. Miller LE, Bhattacharyya R, Miller AL. Diabetes mellitus increases the risk of hospital mortality in patients with Covid-19: systematic review with meta-analysis. Medicine. 2020 Oct 2;99(40):e22439. https://doi.org/10.1097/MD.0000000000022439 PMID:33019426

4. Badawi A, Ryoo SG. Prevalence of comorbidities in the Middle East respiratory syndrome coronavirus (MERS-CoV): a systematic review and meta-analysis. Int J Infect Dis. 2016 Aug;49:129-33. https://doi.org/10.1016/j.ijid.2016.06.015 PMID:27352628

5. $\quad$ Yang JK, Feng Y, Yuan MY, Yuan SY, Fu HJ, Wu BY, et al. Plasma glucose levels and diabetes are independent predictors for mortality and morbidity in patients with SARS. Diabet Med. 2006 Jun;23(6):623-8. https://doi.org/10.1111/j.1464-5491.2006.01861.x PMID:16759303

6. Apicella M, Campopiano MC, Mantuano M, Mazoni L, Coppelli A, Del Prato S. COVID-19 in people with diabetes: understanding the reasons for worse outcomes. Lancet Diabetes Endocrinol. 20201 Sep;8(9):782-92. https://doi.org/10.1016/S2213-8587(20)302382

7. Holman N, Knighton P, Kar P, O'Keefe J, Curley M, Weaver A, et al., Risk factors for COVID-19-related mortality in people with type 1 and type 2 diabetes in England: a population-based cohort study. Lancet Diabetes Endocrinol. 2020 1 Oct;8(10):823-33. https://doi.org/10.1016/S2213-8587(20)30271-0

8. Petrakis V, Panagopoulos P, Papazoglou D, Papanas N. Diabetes mellitus and hypertension as major risk factors of mortality from Covid-19 pneumonia. Exp Clin Endocrinol Diabetes. 2020. https://doi.org/10.1055/a-1325-0381 PMID:33296923

9. Wu Z, McGoogan JM. Characteristics of and important lessons from the coronavirus disease 2019 (COVID-19) outbreak in China: summary of a report of 72314 cases from the Chinese Center for Disease Control and Prevention. JAMA. 2020 Apr 7;323(13):123942. https://doi.org/10.1001/jama.2020.2648 PMID:32091533

10. Al Dawish MA, Robert AA. COVID-19 in people with diabetes: epidemiological perspectives and public health actions in the Middle East and North Africa (MENA) Region. Curr Diabetes Rev. 2021;17(5):e211020187087. https://doi.org/10.2174/15733998166662010 21154839 PMID:33087031

11. Coronavirus disease (COVID-19) technical guidance: Laboratory testing for 2019-nCoV in humans [website]. Geneva: World Health Organization; 2020 (https://www.who.int/emergencies/diseases/novel-coronavirus-2019/technical-guidance/laboratory-guidance/, accessed 26 August 2021).

12. Alguwaihes AM, Al-Sofiani ME, Megdad M, Albader SS, Alsari MH, Alelayan A et al., Diabetes and Covid-19 among hospitalized patients in Saudi Arabia: a single-centre retrospective study. Cardiovasc Diabetol. 2020 Dec 5;19(1):205. https://doi.org/10.1186/ s12933-020-01184-4 PMID:33278893

13. Mantovani A, Byrne CD, Zheng M-H, Targher G. Diabetes as a risk factor for greater COVID-19 severity and in-hospital death: a meta-analysis of observational studies. Nutr Metab Cardiovasc Dis. 2020 Jul 24;30(8):1236-48. https://doi.org/10.1016/j.numecd.2020.05.014 PMID:32571616

14. Yang J, Zheng Y, Gou X, Pu K, Chen Z, Guo Q, et al. Prevalence of comorbidities and its effects in patients infected with SARSCoV-2: a systematic review and meta-analysis. Int J Infect Dis. 2020 May;94:91-5. https://doi.org/10.1016/j.ijid.2020.03.017 PMID:32173574

15. Khan A, Althunayyan S, Alsofayan Y, Alotaibi R, Mubarak A, Arafat M, et al. Risk factors associated with worse outcomes in COVID-19: a retrospective study in Saudi Arabia. East Mediterr Health J. 2020 Nov 11;26(11):1371-80. https://doi.org/10.26719/ emhj.20.130 PMID:33226105

16. Grasselli G, Zangrillo A, Zanella A, Antonelli M, Cabrini L, Castelli A, et al. Baseline characteristics and outcomes of 1591 patients infected with SARS-CoV-2 admitted to ICUs of the Lombardy Region, Italy. JAMA. 2020 Apr 28;323(16):1574-81. https://doi. org/10.1001/jama.2020.5394 PMID:32250385

17. Richardson S, Hirsch JS, Narasimhan M, Crawford JM, McGinn T, Davidson KW, et al. Presenting characteristics, comorbidities, and outcomes among 5700 patients hospitalized with COVID-19 in the New York City area. JAMA. 2020 May 26;323(20):2052-9. https://doi.org/10.1001/jama.2020.6775 PMID:32320003

18. Kruglikov IL, Shah M, Scherer PE. Obesity and diabetes as comorbidities for COVID-19: Underlying mechanisms and the role of viral-bacterial interactions. eLife. 2020 Sep 15;9:e61330. https://doi.org/10.7554/eLife.61330 PMID:32930095

19. Lockhart SM, O'Rahilly S. When two pandemics meet: why is obesity associated with increased COVID-19 mortality? Med. 2020;1(1):33-42. https://doi.org/10.1016/j.medj.2020.06.005 